\title{
Pemasyarakatan Narapidana Narkotika dalam Mewujudkan Kesadaran Hukum
}

\author{
Wiska Watubtaran Rengmas Rahantoknam¹, Erwin Aditya Pratama \\ PERADI Salatiga, Universitas Pancasakti Tegal \\ Masuk: 17 November 2020; Diterima: 30 November 2020; Terbit: 30 November 2020.
}

DOI: $10.24905 /$ diktum.v8i2.101

\begin{abstract}
Assimilation is part of the development process as well as the right of narcotics inmates inside the Penitentiary to mingle directly with the community outside the prison. In the application of assimilation often narcotics inmates commit irregularities that violate the rule of law, irregularities are carried out to obtain narcotics for addicts and for dealers to operate narcotics trafficking from inside prisons, this event indicates that the legal awareness of inmates undergoing the process of assimilation has not shown a success. The problems examined include First, how is the implementation of assimilation for narcotics inmates in Class II A Kendal Correctional Institution. Second, whether narcotics inmates are given special supervision while undergoing the process of assimilation. Third, how is the success rate of coaching narcotics inmates at the stage of assimilation in realizing legal awareness? This research uses the socio-legal approach method, data obtained through interviews and observations, then data processed descriptively analytically. The results showed that the implementation of assimilation of narcotics inmates was carried out in prisons as a preventive effort so as not to fall back on narcotics. Assimilation in prisons is carried out by involving people from outside prisons to carry out activities with narcotics inmates in various aspects such as education, sports, and the arts. Supervision is carried out strictly with certain restrictions by officers, inmate guardians, and also prison intelligence so that inmates do not feel intervened during the assimilation. The level of legal awareness shown by narcotics inmates at Kendal correctional institutions showed positive results in which they showed compliance with the rule of law in general and the rules of the potentiation and did not commit any violations in the process of assimilation.
\end{abstract}

Keywords: Assimilation, Narcotics Inmates, Legal Awareness

\footnotetext{
${ }^{1}$ Coresponding author:

wiskarahantoknam@gmail.com
} 


\begin{abstract}
Abstrak
Asimilasi merupakan bagian dari proses pembinaan dan juga hak narapidana narkotika yang berada di dalam Lembaga Pemasyarakatan untuk berbaur langsung dengan masyarakat yang berada di luar lapas. Dalam penerapan asimilasi kerapkali narapidana narkotika melakukan penyimpangan yang melanggar aturan hukum, penyimpangan dilakukan untuk mendapatkan narkotika bagi pecandu dan bagi pengedar untuk mengoperasikan peredaran narkotika dari dalam lapas, peristiwa ini menandakan bahwa kesadaran hukum dari narapidana menjalani proses asimilasi belum menunjukkan suatu keberhasilan. Permasalahan yang diteliti diantaranya Pertama, bagaimanakah pelaksanaan asimilasi bagi narapidana narkotika di Lembaga Pemasyarakatan Kelas II A Kendal. Kedua, apakah narapidana narkotika diberikan pengawasan khusus pada saat menjalani proses asimilasi. Ketiga, bagaimanakah tingkat keberhasilan pembinaan narapidana narkotika pada tahap asimilasi dalam mewujudkan kesadaran hukum. Penelitian ini menggunakan metode pendekatan socio-legal, data diperoleh melalui wawancara dan observasi, kemudian data diolah secara deskriptif analitis. Hasil penelitian menunjukkan pelaksanaan asimilasi narapidana narkotika dilangsungkan di dalam lapas sebagai upaya pencegahan agar tidak terjerumus kembali pada narkotika. Asimilasi di dalam lapas dilaksanakan dengan cara melibatkan masyarakat dari luar lapas untuk melangsungkan aktifitas bersama narapidana narkotika dalam berbagai aspek seperti pendidikan, olahraga, dan seni. Pengawasan dilakukan secara ketat dengan batasan tertentu oleh petugas, wali narapidana, dan juga intelejen lapas agar narapidana tidak merasa diintervensi selama melangsungkan asimilasi. Tingkat kesadaran hukum yang ditunjukkan oleh narapidana narkotika di lembaga pemasyarakatan Kendal menujukkan hasil positif dimana mereka menunjukkan kepatuhan terhadap aturan hukum pada umumnya dan aturan lembaga pemasyarakatan serta tidak melakukan berbagai pelanggaran dalam proses asimilasi.
\end{abstract}

Kata Kunci: Asimilasi, Narapidana Narkotika, Kesadaran Hukum.

\title{
A. Pendahuluan
}

Indonesia merupakan negara yang berlandaskan atas hukum (lawstaat) dan bukan berlandaskan kekuasaan (machtstaat). Ketentuan ini termaktub di dalam Pasal 1 ayat 3 Undang-Undang Dasar 1945. Secara embrionik gagasan negara hukum pertama kali digunakan oleh Rudolf von Gesit (1816-1895) di dalam bukunya "Das Englische Verwaltunngerechte" tahun 1957 sebagai respon atas kekuasaan yang absolut. Menurutnya harus ada pembatasan dengan cara menempatkan hukum diatas segalanya, artinya bahwa semua tindakan harus didasarkan dan dijalankan menurut ketentuan hukum. (Waluyo 2016)

Tindak pidana narkotika saat ini marak terjadi di Indonesia dan dilakukan oleh berbagai kelompok umur. Pada setiap sendi kehidupan masyarakat selalu terancam dengan adanya barang tersebut. Tindak pidana narkotika bersifat transnasional dilaksanakan dengan modus operandi tertentu dengan dibekengi oleh jaringan organisasi yang luas dan dapat mengancam kehidupan 
masyarakat. Narkotika diedarkan oleh oknum tertentu tanpa melihat dampak yang akan muncul setelah barang haram tersebut diedarkan. Narkotika dapat beredar di berbagai kalangan, baik dalam kalangan birokrasi, kalangan penegak hukum, dan aparat negara. Hal yang memprihatinkan yang dapat terlihat jelas bagaimana narkotika dapat masuk ke bidang pendidikan seperti di kalangan para akademisi, di tingkatan mahasiswa dan juga para pelajar. Peredaran narkotika saat ini telah mencapai tingkatan yang memprihatinkan serta menimbulkan keresahan di masyarakat. Dalam berbagai media massa juga seringkali dijumpai pemberitaan tentang maraknya penggunaan narkotika di berbagai kalangan yang ditemukan sudah meregang nyawa dalam penggunaan dosisnya yang berlebihan. Hal ini merupakan suatu ancaman serius yang perlu untuk diberantas agar rantai peredaran dan penggunaan narkotika dapat segera berhenti. (Agus 2019)

Terpidana kasus narkotika dapat dikategorikan dalam 2 kelompok yaitu yang pertama kelompok pengedar yang merupakan individu atau kelompok yang bertanggungjawab karena melakukan aktifitas penjualan narkoba secara bebas dan telah melanggar/menyalahi peraturan perundang-undangan yang berlaku. Kedua adalah kelompok pecandu yang menggunakan atau menyalahgunakan narkotika dan dalam keadaan ketergantungan pada narkotika, baik secara fisik maupun psikis. Oleh karena itu, apapun tingkat kesalahannya, para terpidana tersebut masih diharapkan dapat menyadari bahwa apa yang telah diputus majelis hakim atas kesalahan mereka adalah merupakan suatu cara atau sarana agar mereka meninggalkan perbuatan tersebut setelah selesai menjalani masa hukuman dan menjadi orang yang berguna bagi bangsa dan negara.

Dengan diundangkannya Undang-Undang Nomor 12 Tahun 1995 Tentang Pemasyarakatan memberikan penguatan terhadap upaya mewujudkan sistem 
pemasyarakatan sebagai tatanan mengenai arah dan batas serta cara pembinaan warga binaan pemasyarakatan berdasarkan pancasila yang dilaksanakan secara terpadu antara pembina, yang dibina, serta masyarakat untuk meningkatkan kualitas warga binaan pemasyarakatan agar dapat menyadari kesalahan, memperbaiki diri, dan tidak mengulangi tindak pidana sehingga dinyatakan bebas dapat diterima kembali oleh lingkungan masyarakat serta secara aktif berperan dalam pembangunan dengan harapan dapat hidup secara wajar sebagai warga masyarakat yang baik dan bertanggung jawab.

Proses asimilasi terhadap narapidana narkotika baik itu pengedar ataupun pecandu patut diberikan berdasarkan ketentuan Perundang-Undangan dan diawasi secara ketat. Hal ini dikarenakan bahwa pada saat asimilasi dilangsungkan dimana narapidana diberikan kesempatan untuk berinteraksi dengan masyarakat. (Dwiatmodjo 2020) Bagi pecandu mereka akan mencari cara untuk memperoleh barang haram tesebut sementara bagi para pengedar mereka akan mencari kesempatan untuk mengoperasikan narkotika dari dalam lapas entah itu dengan kerja sama antara sipir ataukah dengan kunjungan dari pihak luar. Namun seringkali selama asimilasi, narapidana narkotika memiliki peluang untuk mengedarkan narkotika dengan cara-cara tertentu, seperti menghubungi bandar narkotika disaat para petugas lengah dan ada juga yang bekerja sama dengan sipir di lapas untuk membawa barang terlarang ke dalam lapas. Ini menandakan bahwa pembinaan kesadaran hukum seorang narapidana narkotika sebagaimana termaktub di dalam Pasal 3 huruf (F) Peraturan Pemerintah Nomor 31 Tahun 1999 Tentang Pembinaan dan Pembimbingan Warga Binaan Lembaga Pemasyarakatan belum sepenuhnya berjalan dengan maksimal. (Fajar Dian Aryani 2018)

Melihat pelanggaran hukum yang dilakukan oleh terpidana narkotika maka perlu diadakan sebuah penelitian hukum di Lembaga Pemasyarakatan 
Kendal untuk menguji mengenai bagaimana pelaksanaan pemasyarakatan narapidana narkotika pada tahap asimilasi, bagaimana bentuk pengawasan terhadap narapidana narkotika selama proses asimilasi, dan bagaimana tingkat keberhasilan pembinaan narapidana narkotika pada tahap asimilasi di lapas Kendal dalam mencapai kesadaran hokum.

\section{B. Metodologi Penelitian}

\section{Metode Pendekatan}

Berdasarkan dengan permasalahan yang diajukan dalam penelitian ini menggunakan metode pendekatan yuridis empiris yang artinya untuk menganalisis dan mengkaji bekerjanya hukum dalam masyarakat. Menurut Peter Mahmud Marzuki penelitian socio-legal merupakan penelitian yang menempatkan hukum sebagai gejala sosial. Dengan demikian hukum dipandang dari segi luarnya saja dan menitikberatkan pada perilaku individu atau masyarakat dalam kaitannya dengan hukum. (Nurbani 2014)

Dalam penelitian ini yang hendak ditemukan yaitu fakta atau realita mengenai pemasyarakatan narapidana narkotika dalam mencapai kesadaran hukum sehingga tidak hanya mengacu pada aturan yang telah ditetapkan tetapi membutuhkan juga pengamatan dan penilaian secara langsung aktivitas pembinaannya di dalam lembaga pemasyarakatan. Dalam penelitian ini, hukum ditempatkan sebagai variabel terikat dan faktor-faktor non hukum yang mempengaruhi hukum dipandang sebagai variabel bebas. Disamping itu juga hukum dipandang dari segi luarnya saja karena sasarannya berada pada perilaku individu atau masyarakat dalam kaitannya dengan hukum. (Dillah 2015) 
2. Spesifikasi Penelitian

Spesifikasi dalam penelitian ini yaitu deskriptif analitis dimana dalam penelitian menggambarkan keadaan dari objektif yang akan diteliti, kemudian dihimpun data-data yang didapat dalam penelitian kemudian dianalisis. Diharapkan dalam melaksanakan penelitian ini akan memberikan gambaran mengenai pembinaan warga binaan di lapas guna mewujudkan kesadaran hukum warga binaan.

\section{Populasi dan Sampel}

Populasi merupakan sejumlah unit yang mempunyai ciri-ciri atau karakteristik yang sama. Mengingat populasi yang cukup luas dan tidak dapat diadakan penelitian secara keseluruhan, maka populasi yang diambil adalah sebagian untuk diteliti dan dijadikan sebagai sampel penelitian yang dikaji secara cermat dan tepat. Lembaga Pemasyarakatan Kelas II A Kendal dijadikan populasi karena merupakan salah satu lembaga pemasyarakatan yang menampung narapidana kasus narkotika di Jawa Tengah.

Penentuan sampel merupakan salah satu point penting dalam melaksanakan aktivitas penelitian karena akan muncul pertanyaanpertanyaan dalam menentukan siapa saja yang akan dijadikan obyek penelitian. Sampel yang digunakan dalam penelitian ini adalah Non Probability sample yang artinya tidak ada ketentuan pasti sampai sejauh mana sampel yang diambil dapat mewakili populasi, sehingga semuanya tergantung pada peneliti. (Dillah 2015) Adapun yang menjadi sampel dalam penelitian ini adalah Kepala Seksi Bimbingan Narapidana dan Anak Didik Lapas Kelas II A Kendal dan juga beberapa narapidana kasus narkotika. 


\section{Metode Pengumpulan Data}

Dalam penelitian ini, metode pengumpulan data yang dipakai untuk memperoleh data primer dan data sekunder adalah sebagai berikut: Data Primer adalah data yang diperoleh secara langsung dari penelitian di lapangan (field research). Penelitian lapangan ini dilaksanakan dengan cara wawancara, yaitu teknik pengumpulan data dengan cara mengajukan pertanyaan secara langsung kepada responden. Dalam penelitian ini pertanyaan yang digunakan tidak hanya mengacu pada pertanyaan yang disediakan secara tertulis dalam bentuk daftar pertanyaan, tetapi dapat dilakukan pengembangan pertanyaan sepanjang tidak menyimpang dari permasalahan yang diajukan. Dalam hal ini responden yang dipilih dalam penelitian ini adalah:

a) Kepala Lembaga Pemasyarakatan Kelas II A Kendal, hal ini dikarenakan keseluruhan proses pembinaan yang dilakukan selama narapidana menjalani hukumannya di lapas akan diberikan pertanggungjawaban atau laporan kepada Kalapas selaku pimpinan dan pemegang otoritas lapas Kendal.

b) Kepala Kesatuan Pengamanan Lapas Kelas II A Kendal, hal ini dikarenakan bahwa tugas dan kewenangannya yaitu menjaga keamanan dan ketertiban lapas sehingga dapat diperoleh informasi sesuai yang dibutuhkan.

c) Kepala Seksi Bimbingan Narapidana dan Anak Didik Lapas Kelas II A Kendal, hal ini dikarenakan dalam melakukan pembinaan terhadap narapidana, kewenangan dan tanggung jawabnya berada pada Kasie Bimbingan Narapidana dan Anak Didik.

d) Wali Pemasyarakatan Lapas Kelas II A Kendal, hal ini dikarenakan bahwa Wali pemasyarakatan merupakan petugas yang melakukan 
pendampingan terhadap narapidana selama menjalani pembinaan di lembaga pemasyarakatan.

e) Warga Binaan Kasus Narkotika Lapas Kelas II A Kendal, hal ini dikarenakan bahwa narapidana selaku subjek yang sedang menjalani proses asimilasi dan pembinaan yang dapat memberikan beberapa informasi sesuai dengan permasalahan yang diketengahkan.

Data Sekunder adalah data yang diperoleh berdasarkan studi kepustakaan untuk membandingkan antara teori dan kenyataan yang terjadi di lapangan. Lewat studi kepustakaan, pengumpulan data diperoleh melalui buku-buku, surat kabar, dan referensi-referensi lain yang memiliki keterkaitan dengan penelitian ini. Data sekunder ini meliputi:

a) Bahan hukum primer adalah bahan-bahan hukum yang memiliki kekuatan mengikat seperti peraturan perundang-undangan dan peraturan-peraturan lainnya yang terkait. Bahan hukum primer yang digunakan yaitu peraturan perundang-undangan yang berlaku yaitu:

1) Undang-Undang Nomor 12 Tahun 1995 Tentang Pemasyarakatan.

2) Undang-Undang Nomor 35 Tahun 2009 Tentang Narkotika.

3) Peraturan Pemerintah Nomor 31 Tahun 1999 Tentang Pembinaan dan Pembimbingan Warga Binaan Lapas.

4) Peraturan Pemerintah Nomor 32 Tahun 1999 Jo PP Nomor 28 Tahun 2006 Jo PP Nomor 99 Tahun 2012 Tentang Syarat dan Tata Cara Pelaksanaan Hak Warga Binaan Pemasyarakatan.

5) Peraturan Menteri Hukum dan Ham Nomor M.01 PK.04.10 Tahun 2007 Tentang Wali Pemasyarakatan. 
6) Peraturan Menteri Hukum dan Ham Nomor 6 Tahun 2013 Tentang Tata Tertib Lembaga Pemasyarakatan dan Rumah Tahanan Negara.

7) Peraturan Menteri Hukum dan Ham Nomor 21 Tahun 2013 Tentang Syarat dan Tata Cara Pemberian Remisi, Asimilasi, Cuti Mengunjungi Keluarga, Pembebasan Bersyarat, Cuti Menjelang Bebas, dan Cuti Bersyarat.

8) Surat Edaran Direktorat Jenderal Pemasyarakatan Kementerian Hukum dan Ham Nomor PAS-182.PK.01.04.02 Tahun 2016 Tentang Peningkatan Pencegahan Penyelundupan Barang Terlarang di Lapas, Rutan, dan Cabang Rutan.

b) Bahan hukum sekunder adalah bahan hukum yang memberikan penjelasan dan pemahaman mengenai bahan hukum primer, seperti hasil penelitian, karya ilmiah yang dipaparkan oleh akademisi, artikel-artikel, internet, dan juga literature yang memiliki korelasi dengan permasalahan yang diajukan dalam penelitian.

c) Bahan hukum tertier adalah bahan yang dapat memberikan petunjuk dan juga penjelasan terhadap bahan hukum primer dan bahan hukum sekunder, seperti Kamus Besar Bahasa Indonesia, Kamus Hukum, Ensiklopedia, dan lain-lain.

\section{Metode Analisis Data}

Setelah data primer dan sekunder diperoleh, maka analisis data yang digunakan dalam penelitian ini adalah metode kualitatif yang bersifat deskripitif analisis yaitu data yang diperoleh dalam penelitian lapangan diteliti/dianalisis artinya memberikan suatu penjelasan secara logis sistematis. Setelah itu didaptkan suatu gambaran tentang permasalahan 
yang diteliti, kemudian ditarik kesimpulan yang merupakan jawaban dari permasalahan yang diajukan.

\section{Pembahasan}

1. Pelaksanaan Pemasyarakatan Narapidana Narkotika Pada Tahap Asimilasi

Lembaga pemasyarakatan Kelas II A Kendal berada pada jalur pantura (pantai utara) yang didirikan pada tahun 1870 pada masa pemerintahan hindia belanda yang beralamat di jalan alun-alun Nomor 1 Kendal. Letak Lapas Kelas II A Kendal sebelah barat berbatasan dengan jalan habiproyo, sebelah timur berbatasan dengan alun-alun Kendal, sebelah utara berbatasan dengan jalan raya soekarno hatta, dan sebelah selatan berbatasan dengan jalan kampung.

Lapas Kendal memiliki luas tanah $4.015 \mathrm{~m} 2$ dan luas bangunan 3.418m2 dengan status kepemilikan tanah dan bangunan adalah milik Kementerian Hukum dan Ham Republik Indonesia. Bangunan yang ada terdiri dari 2 yaitu perkantoran dan tempat hunian warga binaan. Untuk hunian warga binaan itu sendiri terdiri dari 4 blok yakni Blok Arjuna (untuk narapidana), Blok Bima (untuk tahanan), Blok Punta Dewa, dan Blok Srikandi (untuk narapidana/tahanan wanita) dengan kapasitas penghuni 151 (seratus lima puluh satu) orang. Lembaga Pemasyarakatan Kelas II A Kendal memiliki visi yakni pulihnya kesatuan hubungan hidup, kehidupan dan penghidupan warga binaan pemasyarakatan sebagai individu, anggota masyarakat, dan makhluk Tuhan Yang Maha Esa. Misi yang dimiliki oleh Lapas Kelas II A Kendal adalah melaksanakan perawatan tahanan, pembinaan dan pembimbingan warga binaan pemasyarakatan serta pengelolaan benda sitaan negara dalam rangka 
penegakkan hukum, pencegahan, dan penanggulangan kejahatan serta pemajuan dan perlindungan Hak Asasi Manusia.

Setelah mendapatkan vonis pengadilan, maka terpidana masuk ke dalam lembaga pemasyarakatan yang merupakan tahap awal dimulainya proses pembinaan bagi terpidana, baik fisik maupun mental yang mencakup pendidikan, sekolah, moral, agama, serta berbagai keterampilan agar terpidana setelah menjalani proses pembinaan di Lapas memiliki bekal dalam menghadapi lingkungan hidup yang baru dalam masyarakat.

Asimilasi terhadap narapidana narkotika dilaksanakan secara mandiri di dalam lapas. Hal ini merupakan suatu langkah preventif yang diambil oleh pimpinan lapas untuk menghindari adanya penyimpangan bahkan terjerumusnya kembali narapidana ke dalam pusaran narkotika sehingga tidak ada celah apapun yang dapat digunakan oleh oknumoknum yang tidak bertanggung jawab untuk mengedarkan narkotika. Pembinaan yang diambil oleh pihak lapas merupakan pembinaan yang meminimalisir resiko dan juga berpedoman pada regulasi PP No 99 Tahun 2012 yang menyediakan alternatif asimilasi bagi narapidana narkotika. Disamping itu juga pihak ketiga yang hendak menerima para narapidana yang mendapatkan asimilasi bilamana mengetahui bahwa narapidana tersebut merupakan narapidana kasus narkotika, maka mereka cenderung untuk tidak menerima dan sangat riskan mengingat stigma masyarakat terhadap narkotika yang sudah sangat meresahkan dan mengancam kehidupan bangsa dan negara ini. (Suratman 2016)

Pada hakekatnya asimilasi merupakan suatu langkah untuk membaurkan narapidana ke tengah-tengah masyarakat. Hal yang sama juga terlihat dalam proses asimilasi warga binaan narkotika di dalam lapas, dimana masyarakat luar dapat berbaur dengan para narapidana narkotika 
di dalam lapas. Awalnya masyarakat yang akan masuk untuk berpatisipasi dengan narapidana narkotika memiliki perasaan takut, tetapi seiring berjalannya waktu pihak lapas memberikan pengertian dan jaminan keamanan kepada masyarakat sehingga masyarakat yang hendak berpartisipasi menjadi terbiasa. Kegiatan asimilasi yang dilangsungkan oleh narapidana narkotika dan masyarakat sangat beragam dan merupakan manifestasi dari pembinaan kepribadian terhadap narapidana narkotika tersebut. Adapun kegiatan yang dilaksanakan yakni bermain volley dimana narapidana narkotika bertanding melawan tim yang dibentuk oleh masyarakat. Ada juga kerjasama pihak lapas dengan Pusat Kegiatan Belajar Masyarakat (PKBM) untuk berpartisipasi dari aspek pendidikan kepada narapidana narkotika. Ada juga kerja sama pihak lapas dengan pihak gereja untuk memberikan pemahaman dan pengajaran kepada narapidana narkotika yang beragama nasrani untuk berkembang dan dapat memahami ajaran keagamaannya. Dengan adanya kehadiran masyarakat tersebut dari luar lapas diharapkan dapat memberikan hal-hal yang baru kepada para narapidana untuk dijadikan sebagai inspiratif. (Suratman 2016)

Terdapat berbagai faktor-faktor penghambat yang dihadapi selama proses asimilasi bagi narapidana narkotika dan sangat bervariasi mulai dari minimnya sarana prasarana yang dimiliki lapas, tingkat SDM yang memiliki keahlian di bidang tertentu baik itu pegawai lapas ataupun para instruktur yang juga terbatas, serta ada juga narapidana narkotika yang tidak memiliki keahlian di bidangnya.

Minimnya tempat untuk para narapidana menyalurkan kemampuan yang dimilikinya dalam berbagai karya, sehingga ruangan yang sejatinya bukan diperuntukkan untuk dijadikan tempat melakukan aktifitas 
kegiatan kerja dialihfungsikan menjadi tempat kerja, seperti untuk kegiatan meubel, kegiatan merangkai bunga, pembuatan relief atau lukisan, dan aktifitas seni lainnya.

Tempat untuk melakukan pembinaan terhadap narapidana narkotika pun menggunakan ruangan bimbingan pemasyarakatan, karena yang melakukan pembinaan tidak hanya narapidana narkotika saja tetapi juga narapidana yang non narkotika, sehingga jika dilihat dari daya tampung ruangannya sangatlah terbatas untuk melakukan pembinaan terhadap para narapidana.

Adapun kendala lain yang ditemukan pada saat asimilasi, yakni kemampuan atau bakat dari seorang narapidana narkotika yang relatif. Untuk itu selama proses asimilasi, narapidana narkotika yang tidak memiliki keahlian dalam suatu pekerjaan mengikuti kegiatan yang lain seperti sholat atau mengikuti ceramah keagamaan, menjaga kantin, dan juga olahraga.

Dari segi sumber daya manusia sebagaimana diketahui bahwa di lapas Kendal para petugas yang kompeten di bidang kegiatan kerja memiliki keterbatasan sehingga untuk mengampu para narapidana pun menjadi tidak ideal. Selain itu instruktur pun sangat sulit ditemui untuk memberikan latihan atau bimbingan kerja bagi para narapidana guna memberikan suatu pegangan bagi narapidana agar memiliki keahlian yang dapat dipergunakan ataukah dikembangkan bilamana telah selesai menjalani masa pidananya di lapas.

\section{Pengawasan Khusus Narapidana Narkotika Pada Tahap Asimilasi}

Narkotika lazimnya memiliki sifat ketergantungan bagi para penggunanya, artinya bahwa para warga binaan akan mencari-cari sesuatu yang dapat dijadikan pengganti narkotika tersebut, mengingat lapas 
Kendal merupakan lapas yang bersih dari peredaran narkotika. Pada lapas Kendal terjadi beberapa penyimpangan sekalipun dalam skala kecil yang menurut pandangan mereka berkhasiat memberikan kenyamanan bagi diri mereka. Beberapa hal yang dilakukan oleh warga binaan narkotika untuk memenuhi keinginan mereka tersebut dengan kulit pisang yang dikeringkan kemudian ditumbuk untuk dijadikan tembakau, menggunakan obat antimo, menggunakan obat commix, meminum kopi dengan campuran autan, buah pala yang dikeringkan kemudian dikombinasikan dengan kopi. (Supriyanto 2017)

Dengan kejadian seperti itu, maka pengawasan terhadap narapidana narkotika sangatlah penting mengingat rentan terjadi hal-hal yang tidak dikehendaki. Para narapidana tindak pidana narkotika mendapatkan pengawasan dari para petugas lapas sama seperti yang diterima oleh narapidana tindak pidana lainnya yang sedang menjalani masa pidana di Lapas. Perbedaan yang mencolok dari pengawasan yang dilakukan yaitu bagi narapidana tindak pidana narkotika dilakukan pengawasan secara ketat dengan batasan-batasan tertentu sehingga narapidana narkotika tersebut juga merasa tidak terkekang selama menjalankan asimilasinya di dalam lembaga pemasyarakatan. Tujuan lain juga dilakukan pengawasan secara ketat dengan batasan tertentu ini adalah agar tidak terulang kembali perbuatan-perbuatan yang dapat membahayakan narapidana tersebut ataupun narapidana lainnya. Disamping itu juga pengawasan selama asimilasi bagi narapidana narkotika karena untuk menjaga dan menunjang keberhasilan pelaksanaan asimilasi, jangan sampai ada yang memiliki kepentingan baik itu oknum petugas ataupun pihak luar yang dapat menjadikan proses asimilasi untuk mengedarkan narkotika atau hal-hal lain yang melawan hukum. (Fauzan 2020) 
Bilamana selama asimilasi terjadi pelanggaran yang dilakukan oleh narapidana maka sesuai dengan ketentuan dalam Pasal 39 Peraturan Pemerintah Nomor 99 tahun 2012 Tentang Syarat dan Tata Cara Pelaksanaan Hak Warga Binaan Pemasyarakatan, maka asimilasi terhadap narapidana tersebut dicabut. Pada huruf (a) dinyatakan bahwa untuk tahun pertama setelah dilakukan pencabutan tidak dapat diberikan remisi, asimilasi, pembebasan bersyarat, cuti menjelang bebas, dan cuti mengunjungi keluarga. Pada huruf (b) dijelaskan bahwa dalam hal narapidana yang dicabut asimilasinya untuk kedua kalinya, yang bersangkutan tidak diberikan hak asimilasi, pembebasan bersyarat, cuti menjelang bebas, dan cuti mengunjungi keluarga.

3. Tingkat Keberhasilan Pemasyarakatan Narapidana Narkotika Pada Tahap Asimilasi Dalam Mewujudkan Kesadaran Hukum

Apabila seseorang memiliki pemahaman dan menjalankan aturan hukum dalam masyarakat maka itu merupakan suatu langkah kongkrit dalam mencegah terjadinya berbagai kejahatan. Namun untuk mencapai hal tersebut yakni masyarakat yang memiliki ketaatan hukum haruslah diukur juga dari beberapa hal yakni tingkat pendidikannya, keadaaan sekitarnya, dan sebagainya. Pemikiran yang dikemukakan oleh Krabbe dalam buku Satjipto Rahardjo yang berjudul Sosiologi Hukum Perkembangan Metode dan Pilihan Masalah yang mengatakan bahwa tidak ada peraturan yang dapat mengikat manusia, kecuali ia menerimanya berdasarkan keyakinannya sendiri. (Rahardjo 2010)

Berdasarkan pemikiran tersebut maka kesadaran hukum seseorang dapat dikatakan bersifat relatif. Hal yang sama pun dapat terjadi bagi para narapidana tindak pidana narkotika di lapas Kendal. Selain faktor ekonomi dan juga lingkungan, salah satu faktor lainnya yaitu faktor pendidikan 
dimana tingkat pendidikan para warga binaan narkotika di lapas Kendal sangat beragam, yakni dari tingkat SD, SMP, dan SMA. Semakin meningkat pendidikan seseorang tidak menjamin bahwa dia dapat mengetahui ketentuan-ketentuan hukum yang telah ditetapkan. Lazimnya setelah orang tersebut melakukan tindak pidana terlebih dahulu, barulah dia menyadari telah melakukan beberapa penyimpangan. Terlebih lagi dalam hal tindak pidana narkotika, dimana narkotika terbagi dalam 3 golongan dan masing-masing golongan tersebut terbagi dalam beberapa jenis narkotika yakni golongan I yang terdiri dari 26 macam, golongan II yang terdiri 87 macam, dan golongan III yang terdiri 14 macam. (Supriyanto 2017)

Pembinaan terhadap narapidana narkotika di lapas Kendal telah berjalan dengan baik. Perkembangan para narapidana pun menunjukkan hasil yang positif selama mereka menjalani proses asimilasi. Hal ini terlihat dimana para narapidana tersebut yang telah menunjukkan kesadaran hukum, perkembangan kepribadian, keadaan psikologis selama berlangsungnya proses asimilasi dan pembinaan di lapas diusulkan oleh tim pengamat pemasyarakatan kepada pimpinan lapas untuk mendapati Cuti Bersyarat, Cuti Menjelang Bebas, Cuti Mengunjungi Keluarga, dan juga Pembebasan Bersyarat.

Parameter keberhasilan pembinaan kesadaran hukum bagi narapidana narkotika selama menjalani proses asimilasi di dalam lapas Kendal sebesar $80 \%$. Jelas terlihat bahwa selama diluar lapas dan di dalam lapas terjadi perbedaan yang sangat signifikan, seperti pada saat diluar lapas warga binaan narkotika tersebut belum memahami batasan-batasan namun setelah menjalani masa pidana di dalam lapas dengan mengikuti berbagai rambu-rambu atau ketentuan hukum maka itu merupakan 
indikator bahwa telah memahami aturan-aturan yang ada, baik itu aturan lapas ataupun aturan hukum secara umum. (Supriyanto 2017)

Perlakuan kepada warga binaan narkotika di lapas Kendal dalam menjalani asimilasi Bagi pecandu narkotika yang telah menunjukkan kesadaran hukum yang tinggi diberikan reward oleh lapas untuk direhabilitasi dengan dibentuk tim khusus yang didukung oleh Badan Narkotika Nasional Provinsi Jawa Tengah dengan harapan ada perubahan positif. Sementara bagi para pengedar diberikan peringatan agar tidak melakukan hal-hal yang bertentangan dengan kebijakan lapas dan juga ketentuan hukum serta diawasi oleh BNNP (Badan Nasrkotika Nasional Provinsi) Jawa Tengah untuk memantau para warga binaan dalam kapasitasnya sebagai pengedar narkoba guna membuktikan kesungguhannya untuk patuh terhadap aturan.

\section{Simpulan}

Pelaksanaan asimilasi terhadap warga binaan yang ada di lapas Kendal dilakukan di lapas sebagai upaya pencegahan agar warga binaan tidak kembali terjerumus ke dalam pusaran narkotika. Warga binaan narkotika melakukan beberapa kegiatan selama proses asimilasi seperti melakukan aktifitas seni yakni melukis, membuat bunga, melakukan bersih-bersih blok hunian, mengikuti ceramah keagaaman, dan menjaga kantin. Disatu sisi selama asimilasi juga bagi warga binaan narkotika dapat mengadakan hubungan dengan masyarakat luar. Hal ini terlihat dari adanya kunjungan tim volley dari masyarakat ke lapas untuk melangsungkan kegiatan olahraga bersama warga binaan, kunjungan masyarakat luar untuk memberikan kegiatan kesenian kepada para narapidana guna meningkatkan keahlian dalam bidang seni, kerjasama pihak lapas dengan Pusat Kegiatan Belajar Masyarakat (PKBM), serta kerja sama pihak lapas dengan pihak gereja untuk memberikan pemahaman dan pengajaran kepada 
narapidana narkotika yang beragama nasrani untuk berkembang dan dapat memahami ajaran keagamaannya.

Pengawasan terhadap narapidana selama berlangsungnya proses asimilasi dilakukan secara ketat dengan batasan tertentu, artinya bahwa pengawasan tetap berjalan namun tidak membuat warga binaan merasa dikekang atau diintervensi. Esensi diadakannya pengawasan terhadap narapidana narkotika di lapas Kendal adalah untuk mencegah terjadinya penyelewengan yang dilakukan oleh warga binaan dan juga agar tidak kembali kecolongan dengan pergerakkan warga binaan narkotika yang begitu kompleks seperti mencari-cari sesuatu yang dapat membuat nyaman selama melangsungkan kegiatannya di lapas. Untuk mempermudah pengawasan juga lapas Kendal melakukan pemisahan blok agar warga binaan non narkotika tidak terpengaruh dengan warga binaan narkotika. Pengawasan dilakukan oleh wali pemasyarakatan, oleh petugas lapas, dan juga oleh suatu tim intelejen yang dibentuk oleh lapas.

Kesadaran hukum yang dimiliki oleh warga binaan narkotika di dalam menjalani proses asimilasi di lapas Kendal menunjukkan hasil positif dengan persentase keberhasilan $80 \%$. Tingkat pendidikan yang kurang dari seorang warga binaan narkotika selama berada di luar membuat dengan mudahnya dapat tersandung dengan hukum. Selama berlangsungnya asimilasi di dalam lapas warga binaan diberikan pemahaman atau pengertian dari lapas mengenai aturan-aturan di dalam lapas maupun aturan hukum secara umum serta diadakannya razia blok hunian sehingga potensi kesadaran hukum mulai muncul dari diri masing-masing warga binaan narkotika. Terlihat jelas dimana masing-masing warga binaan yang menjalani asimilasi telah melakukannya dengan baik dan juga syarat-syarat integrasi telah dipenuhi sehingga melalui tim pengamat pemasyarakatan telah diajukan permohonan untuk masa integrasi yakni pengurusan pembebasan bersyarat. 


\section{Daftar Pustaka}

Agus, Dwi. 2019. "Perbandingan Hukum Akherat." Jurnal Akherat 32-42.

doi:10.24905/diktum.v8i1.81.

Dillah, Suratman \& H. Philips. 2015. Metodologi Penelitian Hukum. Bandung: Alfabeta.

Dwiatmodjo, Haryanto. 2020. "Pelaksanaan Pidana dan Pembinaan Narapidana Tindak Pidana Narkotika (Studi terhadap Pembinaan Narapidana di Lembaga Pemasyarakatan Narkotika Klas IIA Yogyakarta)." Prespektif 18 (2): 64-73. doi:http://dx.doi.org/10.30742/perspektif.v18i2.115.

Fajar Dian Aryani, Erwin Aditya Pratama. 2018. "Perlindungan Terhadap Disabilitas Dalam Kebijakan Hukum Pidana (Sebagai Pelaku Maupun Korban)." Justicia Sains (Fakultas Hukum Universitas Saburai Lampung) 3 (2): 90 - 103. doi:https://doi.org/10.24967/jcs.v3i2.360.

Fauzan. 2020. "Pelaksanaan Pemberian Asimilasi Bagi Narapidana Sebagai Penerapan UndangUndang Pemasyarakatan." Syntax Literate: Jurnal IImiah Indonesia 5 (9): 846-860. doi:http://dx.doi.org/10.36418/syntax-literate.v5i9.1597.

Nurbani, Salim HS \& Erlies Septiana. 2014. Penerapan Teori Hukum Pada Penelitian Tesis Dan Disertasi. Jakarta: Rajawali Pers.

Rahardjo, Satjipto. 2010. Sosiologi Hukum Perkembangan Metode dan Pilihan Masalah . Yogyakarta: Genta Publishing.

Supriyanto, interview by Supriyanto. 2017. Wawancara KPLP Lapas Kendal Kendal, Jawa Tengah, (feburari 8).

Suratman, T. 2016. "Pembinaan Narapidana Narkotika dan Obat Obatan Berbahaya (Narkoba) dalam Perspektif Kehidupan Religiusitas." Jurnal Cakrawala Hukum (University Merdeka of Malang) 66-81. doi:doi:10.26905/idjch.v7i1.1783.

Waluyo, Bambang. 2016. Penegakkan Hukum Di Indonesia. Jakarta: Sinar Grafika.

\section{References}

Agus, Dwi. 2019. "Perbandingan Hukum Akherat." Jurnal Akherat 32-42. doi:10.24905/diktum.v8i1.81.

Dillah, Suratman \& H. Philips. 2015. Metodologi Penelitian Hukum. Bandung: Alfabeta.

Dwiatmodjo, Haryanto. 2020. "Pelaksanaan Pidana dan Pembinaan Narapidana Tindak Pidana Narkotika (Studi terhadap Pembinaan Narapidana di Lembaga Pemasyarakatan Narkotika 
Klas IIA Yogyakarta)." Prespektif 18 (2): 64-73.

doi:http://dx.doi.org/10.30742/perspektif.v18i2.115.

Fajar Dian Aryani, Erwin Aditya Pratama. 2018. "Perlindungan Terhadap Disabilitas Dalam Kebijakan Hukum Pidana (Sebagai Pelaku Maupun Korban)." Justicia Sains (Fakultas Hukum Universitas Saburai Lampung) 3 (2): 90 - 103. doi:https://doi.org/10.24967/jcs.v3i2.360.

Fauzan. 2020. "Pelaksanaan Pemberian Asimilasi Bagi Narapidana Sebagai Penerapan UndangUndang Pemasyarakatan." Syntax Literate: Jurnal Ilmiah Indonesia 5 (9): 846-860. doi:http://dx.doi.org/10.36418/syntax-literate.v5i9.1597.

Nurbani, Salim HS \& Erlies Septiana. 2014. Penerapan Teori Hukum Pada Penelitian Tesis Dan Disertasi. Jakarta: Rajawali Pers.

Rahardjo, Satjipto. 2010. Sosiologi Hukum Perkembangan Metode dan Pilihan Masalah . Yogyakarta: Genta Publishing.

Supriyanto, interview by Supriyanto. 2017. Wawancara KPLP Lapas Kendal Kendal, Jawa Tengah, (feburari 8).

Suratman, T. 2016. "Pembinaan Narapidana Narkotika dan Obat Obatan Berbahaya (Narkoba) dalam Perspektif Kehidupan Religiusitas." Jurnal Cakrawala Hukum (University Merdeka of Malang) 66-81. doi:doi:10.26905/idjch.v7i1.1783.

Waluyo, Bambang. 2016. Penegakkan Hukum Di Indonesia. Jakarta: Sinar Grafika. 